\section{Facts Shifting to the Left: From Postmodernism to the Postfactual Age}

\section{ALBRECHT KOSCHORKE}

TRANSLATED BY MICHAEL THOMAS

TAYLOR AND SASHA ROSSMAN
ALBRECHT KOSCHORKE is professor of German literature and literary studies at the University of Konstanz and extraordinary professor at the University of Pretoria. His recent publications include On Hitler's Mein Kampf: The Poetics of National Socialism (MIT Press, 2017) and Fact and Fiction: Elements of a General Theory of Narrative (De Gruyter, 2018).

\section{The Dark Shadow of Culturalism}

HOW POSTMODERN IS POPULISM? IS THERE A HIDDEN LEGACY OF THE 1968 MANIFESTOS IN TODAY'S RIGHT-WING PROTEST CULTURE? IN RE-

cent years, questions like these have often been posed in a more or less polemical manner. They should be reconsidered in a more sober, nuanced way. In academia, they are of far more than merely historical interest since unlike the hairstyles, clothing fashions, body culture, and living spaces from the late 1960s, many of the theories from that period are still regarded as contemporary. Above all, this applies to poststructuralism as a collective name for the impulses of what is often called French theory, which have set the tone in the humanities for two generations. However, the problem with the continuing topicality of poststructuralist and postmodern ways of thinking is that many of their elements are becoming virulent under completely changed political circumstances.

To this day, poststructuralism and its international advancements form the most important foundation for cultural studies, which began to take shape institutionally in the 1970s in the West and then set off on a global march of triumph. Poststructuralism was instrumental in establishing the dominance of cultural approaches in the humanities and parts of the social sciences. It thus contributed to a shift in which the templates for representing conflictual social processes were largely replaced. Conflicts were no longer described primarily vertically, as material class conflicts, but increasingly horizontally, as struggles for recognition and interpretive sovereignty between different social worlds.

At the same time, however, a different kind of culturalism developed outside liberal academic circles, bringing with it everything that French theory abhors: essentialism, fundamentalism, ethnonationalism. Understanding the social-structural change underlying the synchronous history of these two developments merits an investigation of its own. In any case, it should be noted that the expansion of cultural studies is accompanied by a dark shadow, however opposed these polit-

(C) 2019 ALBRECHT KOSCHORKE 
ical preferences may be. The fact that there are points of contact between a leftist and a rightist culturalism has become clear in the helplessness with which liberals must watch their arguments being appropriated by right-wing populists-in order to play identity politics by scapegoating minority groups and social elites-and in the criticism of democratic institutions that follows from these practices.

The current political situation demonstrates, with particular clarity, the fatal effects of this kind of culturalism. The most explosive consequences arise in the field to which these PMLA essays are devoted: the discourse about the production of facts or-as work in cultural studies often likes to write-"reality."

\section{The Decline of Colonialism and the Rise of Theory}

What perspective do we gain on poststructuralism if we do not read it and thus perpetuate it from within, as it were, but rather attempt to understand it with an estranged gaze, by focusing on its historical determinants? Poststructuralism, the most fully theorized outgrowth of postmodernism, flourished in the immediate aftermath of the Algerian War and other struggles for independence in former European colonies. Its rise coincided with developments that witnessed Europe's geopolitical eclipse and that brought an end to the continent's claims to intellectual hegemony. As a consequence, poststructuralism aimed to critique and self-reflexively dismantle European philosophical traditions. Its principle objects of inquiry were accordingly European metaphysics and the corresponding models of world-building based on notions of origin, ground, presence, meaning, identity, center, unity, reason, and truth. Counter to such categories, poststructuralism developed a new conceptual vocabulary that privileged decentering, circulation, and permanent exchange, as well as displacement and delay, pluralism and relativism.
Today, anyone who picks up the books on theory that were widely read at that time will notice how close two incompatible textual gestures come to each other. One of them is still laboring with the death of God and, consequently, with the loss of metaphysical guarantees for the world-or, in Derridean terms, with the withdrawal of the "transcendental signified." Again and again, it is argued that the chain of linguistic signifiers has become detached from the signified, referring to nothing outside the text. The talk of the emergence of "simulacra" (Baudrillard) or the dissolution of "la bonne et belle matière" ("good old matter" [Lyotard]) barely conceals a nostalgic sense of loss characteristic of modern cultural criticism at large.

At the same time, in deconstructing essentialisms, downgrading claims to truth to the effects of language games, and subverting meaning, the theorists of poststructuralism pursued an antihegemonic project that rebelled against the repressive character of existing structures of making sense. They thus acknowledged the postcolonial present, which for some of them (perhaps most prominently Derrida, who was born in Algeria) had immediate biographical resonances, and their philosophical program corresponded with postcolonial efforts in the so-called Third World to liberate former colonial subjects from the scientific-technical, normalizing imperatives and worldviews of the West. The spectrum of postcolonial theories has continued to further develop and elaborate these approaches up to the present day. Their tenets can be called relativist in the sense that they sought to upend centuries of Western linguistic dominance that monopolized claims on the nature of reality. In contrast, poststructuralist thought attempted to mobilize and provide legitimacy for subaltern and "peripheral" speakers, actors, alternative ontologies, or-most recently"epistemologies of the South" (Sousa Santos).

A shared leftist political outlook thus connects poststructuralist critiques of Western 
ontology, which sometimes have nostalgic hues, with the emancipatory movements of the former Third World. However, it seems advisable to consider the idea that globalized postcolonial theory is still strongly tied to intra-European disputes and remains circumscribed by their horizon. Over a period of three to four decades, postcolonial theory thus offered thinkers from the former colonies-most of whom had passed through the educational system in the English-speaking world and attained academic positions in the United States or Great Britain-a discursive location, as it were, halfway between the subaltern subjectivity of colonized peoples and the institutions and styles of thought of Western hegemony. In the meantime, there is a sense that the weakening of these hegemonic constellations also entails the weakening of their critical potential. Postcolonial terms are of only limited value in explaining much of what is happening today on the world's stage. For example, Lyotard's grand narrative of the end of all grand narratives, approvingly cited again and again to this day, obscures the otherwise plainly visible fact that those grands récits once believed to have been overcome are proliferating within the Western world, not only outside it: in the context of Islamism as well as in the growing militarization-at times, by means of grand narratives - of ethnonationalist efforts.

\section{Controversies around Constructivism}

From its outset, the "poststructural turn" faced highly polemical reactions. Its proponents were accused of obscurantism and irrationality. In the so-called science wars of the 1990 s, poststructuralism's insistent questioning of truth and references to the real were challenged by a fact-oriented approach to knowledge that also sprang from the political left. Such criticism, however, did not hinder the successful canonization of authors perceived as belonging to poststructuralism, from Jacques Lacan and Roland Barthes to
Judith Butler. Some of the arguments put forward by critics of poststructuralism were simply seen as naive and backward-looking, and often as a symptom of the EuropeanWestern supremacy that needed to be overcome. Cultural and postcolonial studies in the last quarter of the twentieth century were primarily devoted to developing a theoretical language commensurate with the demand for a pluralistic, decentralized epistemology that broke successfully with a continued academic colonization of the world by the West and its opinion leaders. The imperative to take gender relations into account and to acknowledge the integral and foundational roles of minority groups and hybrid constellations as well as diasporic and migratory realities could not dovetail with a monolithic notion of science and knowledge. As a result, poststructural scholars tended to opt for-indeed needed to adopt - a methodological position that embraced pluralistic constructivism over a unifying realism. Almost reflexively, scholars trained in cultural studies asked whose reality was being privileged as "realistic." The counterclaim that social reality could not merely be constructed and that its interpretation could not simply rely on the arbitrariness of social actors prompted a variety of reactions attempting to produce a compromise between the two positions, like the idea that there may well be a "hard kernel" of the real but that this kernel can only become socially effective when mediated through linguistic representation and cultural appropriation. Such compromises, however, suspended the urgency of the problem without offering a solution (Koschorke 16-19).

It has recently become obvious that the success of the poststructural paradigm was partly due to the relatively stable political framework of the historical period in which it emerged. Constructivism as it is implicated in poststructuralist theory, we now see, flourished on the foundations of a liberal political order-on the silent presupposition 
of liberalism's benevolent pluralism and its high estimation of diversity and difference. In academic spheres, too, the "dogma of a 'constructed' world and the euphoria of its 'destabilization'" profited from the stability and social exclusivity of institutions-including the educational system itself-that were, in a way, taken for granted (Gumbrecht). The political mission of the university appeared to be clearly defined: right-wing ideologies (racism, patriarchy, nationalism) were essentialist whereas deconstruction or genealogical demystification (as practiced by Foucault) constituted a left-wing enterprise that was critical of power. This enterprise was bolstered by a certainty, either open or silent, that the architecture of ideology could be shaken, or torn asunder, if one could prove that ideology did not spring from an essential substance, or from a deep well of origin, but rather was created through speech acts alone.

Friedrich Nietzsche was the most important source of inspiration for the genealogical analysis of claims to power and of the strategies of legitimation that underpinned them. Yet Nietzsche also provided the slogan legitimizing political action in the absence of any reasons or substance for such claims: the "will to power." Insofar as the will to power amounts to mere decisionism with no care for the validity of its justifications, it cannot be deconstructed. This fact marks one indisputable weakness of the poststructuralist critique of power, which hit its target only under the premise that strategies of exclusion based on ethnicity, race, nationality, or gender depend on the staying power of the reasons they deploy and thus suffer a blow when their foundations are removed.

In practice, however, the weapons of deconstruction have shown themselves to be blunt. Ideological boundaries may be unmasked as constructions lacking any substance. But this does not prevent them from regenerating again and again-as long as they are backed by a will to power and can attract collective energies. However pertinent the critique of such hegemonial practices may be, it finds itself chronically on the defensive.

\section{From Ideology Critique to the "Postfactual" Era}

From the 1990s on, the political conditions that frame the coordinates of contemporary theory have dramatically shifted-even turned upside down. The possibility that a left-wing, emancipatory cultural relativism, or constructivism, might reveal itself to have false friends became clear, at the latest, with the publication in 1996 of Samuel P. Huntington's influential The Clash of Civilizations and the Remaking of World Order-a map of supposed cultural divides that has been warmly received by ethnonationalists around the world. This possibility became even clearer when the critique of Western scientific rationalism suddenly found itself uncomfortably close to the positions of creationists and, most recently, of climate-change deniers on the right. In this manner, a growing chunk of leftist political discourse was taken over by its political opponents. The left finds itself confronted with the disconcerting fact that some of the arguments it previously used against neoliberalism as a political-economic system that it coded as right-wing are now being used by the right wing itself to criticize globalization and neoliberalism. Even the discrediting of the principle of political representationthat is, of the claim to speak on behalf of somebody else, which was a mainstay of French theory-is now being adapted to right-wing attacks on representative democracy. The right mounts these attacks with an anarchic joy reminiscent of the leftist protest culture of the 1960s and beyond. Poststructural critique of democratic institutions has, in this way, found unexpected and very unwelcome "allies," perhaps most notoriously in Steve Bannon, with his call to "deconstruct" the American state (Rucker and Costa). 
The social theories of the 1960s articulated themselves under the sign of the Marxist notion of base-superstructure relations and adopted a form of ideology critique derived from these structural relations. Ideology critics of a classic, Marxist vein thus attacked false consciousness with a confidence that this could be done from an objective point of view. For poststructuralists of various stripes, the notion that one could speak from an extraterritorial perspective outside language and society-a perspective of absolute truthwas no longer considered tenable. Critical focus, therefore, was increasingly directed at the discourse of truth itself and the ways in which every discourse was enmeshed in power structures. A pluralization of the concept of knowledge went hand in hand with this development. One of the leading principles of recent histories of knowledge was that knowledge should be treated as whatever historical or foreign cultures consider to be evident-even if that so-called knowledge failed to meet current scientific standards. At times, the symmetrical relation that contemporary anthropology and sociology of science erected between self and other was even applied to the distinction between correct and incorrect knowledge, in order to erode the power relations that undergirded these categories. These epistemological symmetries, however, could only be upheld as long as the methods and institutional conditions of knowledge production remained fundamentally unchallenged. Since this is no longer the case in many Western countries, the situation has changed decisively. The political developments in the United States-whose government now openly propagates an antieducation and antiscience message, echoed by other Western states governed by right-wing populists-have led even the most hardened cultural constructivists to call for an embrace of indisputable scientific facts, to plead for rational discourse and for drawing authority from a consensus of experts. These appeals differ at least in style, if not in substance, from their previously articulated principles.

Similar reversals in modes of argumentation can also be identified in the news industry. There were many reasons why the "bourgeois press" was a long-standing target of left-leaning social critics. Poststructuralist critique of mainstream news focused on the media's claims to reliably and objectively represent the public sphere. In the meantime, however, the press has found surprising defenders in its erstwhile opponents. The consistent attacks on traditional, or "mainstream," media by populist propaganda platforms for spreading "fake news" have dramatically shifted the coordinates of the media landscape. One is reminded of Victor Klemperer's observation that the Nazis' favorite grammatical operation was the deployment of quotation marks to discredit news that contradicted their propaganda (78-80).

The rise of social media contributes in its own way to the deconstruction of the representative, public sphere that was the foundation of the traditional modern media landscape. Social constructivism is based on the idea of a multiplicity of worlds and worldconstituting identities and viewpoints. And this imperative found a surprisingly wellsuited correspondence and realization in the World Wide Web. The liberal model of a public sphere defined by a communal effort to search for and uncover truth appears, in retrospect, to have deeply depended on the relations that governed modern print culture, with its centering and centralizing effects.

As decisive as current developments have been, however, one would have to turn a remarkably blind eye to history in order to diagnose these events as ushering in a "postfactual" epoch. This expression alone indicates how fully the world of theory has shifted. The notion of the language game once defined the rubric of postmodernism and was even celebrated as a break from the restrictive bounds of modernity. In recent times, 
however, this game has become an arena of systematic manipulation. And what started as part of a liberatory, leftist project seems to have turned into an instrument for advancing the power claims of right-wing, sometimes extremist, movements.

\section{Longue Durée: The Real and the Modern}

This essay was written in the context of Konstanz University's doctoral program Das Reale in der Kultur der Moderne (The Real in the Culture of Modernity). When this program was established, in 2010, the current radicalization was not yet apparent. At that time, our intention as cultural scientists was primarily self-ironic: after so much discussion in the disciplines that were involved in the doctoral program about concepts of the symbolic and the imaginary, we wanted to once again inquire about the third, even more difficult, perhaps mercurial, concept in the triad of linguistic terms: the real. It struck us that, in current theories, this concept of the real always comes across only as an unpleasant concession, a theoretical remainder that cannot be accommodated-recognizable even in the typography of texts by the fact that real is almost always placed in quotation marks. Instead of attributing the precarious status of the real exclusively to a postmodern condition, we looked at a larger context: the quandary that cultural studies faces in dealing with the real that is posited to exist beyond social constructions and cultural symbolizations. Ultimately, this context is given by the epoch of modernity as a whole. Without taking sides in the controversy between constructivists and realists, we were guided in our research by the hypothesis that the withdrawal of the real is a fundamental feature of modern epistemologies and aesthetics in general. To the extent that this withdrawal enables greater flexibility in dealing with heterogeneous regimes of truth, it can be regarded as "socially functional," however un- satisfactory this conclusion may be from the perspective of epistemological critique.

This thesis has proved to be tenable. However, it is still an unresolved question which paths might lead from an elevated semiotic vantage point characterized by such generalization to the practical requirements we find on the ground, as it were-especially under increasingly aggravating political conditions. If we contend that it is precisely the unknowability of the thing-in-itself that renders modern societies pluralistic, multiperspectival, and elastic by establishing diverse references to reality, then what means are we left with to argue against targeted disinformation or even just against the instrumental use of personalized realities? Or, if we make the concept of ontology plural-following, for example, the anthropologist Philippe Descola, who granted the Achuar people in the Amazon rain forest and their system of kinship between human beings and animals an ontological claim in their own right, which would stand on an equal footing with the reality principle of modern Western science (60-61) - what do we do with the ontological claims of white supremacists? Does the recognition of the alterity of others and their worldview depend on an unspoken, socially romantic notion of caring defined by a capacity for sympathy? Or does it simply depend on the fact that these others are judged inferior from the outset and that the affirmation of their worldview accordingly poses no risk because it has no consequences?

Several attempts have been made in recent years to restore a strong concept of epistemological realism, but they have not proved convincing-from either a philosophical or a cultural-theoretical point of view (Koschorke 19-23). Nevertheless, we cannot close our eyes to the dilemma faced by theories in cultural studies that not only stand in the long tradition of modern skepticism vis-à-vis reality but also view themselves as committed to a reflexive critique of forms of Western 
universalism and the monopolies on truth claimed by its discourses of rationality. Given the political challenges we face today, these theories offer only weak normative backing and little practical guidance in the fight over the power to define true-or real-reality.

There have been many recent debates about the extent to which relativism, constructivism, diversity, and identity politics in cultural studies, combined with the neglect of social concerns (such as inequality), have helped right-wing populists strategically adopt leftist forms of thought and practices of protest. Most noticeable in these debates is the hubris of left-wing academia, which is sometimes evident even in its self-castigation. Yet one thing remains as important as working through historical failings: the question of how we can lead cultural studies, and that segment of the public sphere over which it still holds some influence, out of the dead zone into which the discipline has maneuvered itself, following decades of deessentialization, doubt about norms, and institutional critique-without giving up the emancipatory potential and cognitive achievements of poststructuralist theories and their global advancement.

\section{Works Cited}

Baudrillard, Jean. Simulacra and Simulation. 1981. U of Michigan P, 1994.

Descola, Philippe. Beyond Nature and Culture. U of Chicago P, 2013.

Gumbrecht, Hans U. "Derrida und die Folgen: Was ist aus der Dekonstruktion geworden?” NZZ, 6 Dec. 2015, www.nzz.ch/feuilleton/was-ist-aus-der-dekonstruktion -geworden-1.18657732.

Klemperer, Victor. LTI: Notizbuch eines Philologen. 14th ed., Reclam, 1996.

Koschorke, Albrecht. "Das Mysterium des Realen in der Moderne." Auf die Wirklichkeit zeigen: Zum Problem der Evidenz in den Kulturwissenschaften; Ein Reader, edited by Helmut Lethen et al., Campus, 2015, pp. 13-38.

"Kurze Zusammenfassung des Profils / Short ProfileOverview." Graduiertenkolleg: Das Reale in der Kultur der Moderne, Universität Konstanz, www.uni -konstanz.de/reales/.

Lyotard, Jean-François, et al. "Les immatériaux." Press release. Centre Georges Pompidou, 8 Jan. 1985, www .centrepompidou.fr/media/document/de/0d/de0d76 bbe203394435216a975bea8618/normal.pdf.

Rucker, Philip, and Robert Costa. "Bannon Vows a Daily Fight for 'Deconstruction of the Administrative State." The Washington Post, 23 Feb. 2017, www .washingtonpost.com/politics/top-wh-strategist -vows-a-daily-fight-for-deconstruction-of-the -administrative-state/2017/02/23/03f6b8da-f9ea-11e6 -bf01-d47f8cf9b643_story.html?noredirect=on\&utm term $=.9 \mathrm{~b} 41 \mathrm{~d} 069798 \mathrm{~b}$.

Sousa Santos, Boaventura de. Epistemologies of the South: Justice against Epistemicide. Routledge, 2014. 